\title{
KLAUSA KOMPLEMEN \\ DALAM KALIMAT TRANSFORMASI SEMATAN
}

\author{
Suhardi \\ Jurusan Pendidikan Bahasa dan Sastra Indonesia \\ Fakultas Bahasa dan Seni, Universitas Negeri Yogyakarta
}

\begin{abstract}
This article reexamines Samsuri's concept of a complement clause. A complement clause in an embedded transformed sentence functions to complement a noun phrase (as a subject or an object), a verb phrase, an adjective phrase, a numeral phrase, and a prepositional phrase (as a predicate in a matrix clause). The complement clause embedded into a matrix clause complements a certain phrase in the matrix clause. Embedding a complement clause into a matrix clause uses certain embedding particles. The relational meaning of the complement clause and the main clause in an embedded transformed sentence can be identified on the basis of the syntactic meaning of the embedding operator employed. A complement clause as a combined clause complements a certain phrase in a main/matrix sentence, whereas an adverbial clause is the basic clause that gives explanation to the main/matrix sentence.
\end{abstract}

Keywords: complement clause, matrix cluse, combined clause, embedded transformation

\section{A. PENDAhuluan}

Tulisan ini dimaksudkan untuk mengkaji ulang atas "konsep klausa komplemen dalam kalimat transformasi sematan" yang dikemukakan oleh Samsuri, baik dalam buku Analisis Bahasa (Cetakan ke9, 1994) maupun Tata Kalimat Bahasa Indonesia (Cetakan ke-1, 1985). Kajian ini dilandasi oleh teori Sintaksis (Ramlan, 1981) dan Transformational Grammar (Radford, 1988).

Kajian ini diawali dari pengungkapan konsep klausa komplemen, pengungkapan permasalahan di dalamnya yang disertai pembahasan terhadap subpermasalahan yang ada, baik secara teoretis maupun praktis. Subpermasalahan yang akan dijadikan fokus kajian dalam tulisan ini, antara lain (1) konsep dasar klausa komplemen, (2) fungsi klausa komplemen terhadap klausa utama atau klausa inti, (3) makna hubungan klausa komplemen dengan klausa utama, dan (4) komparasi antara klausa komplemen dan klausa keterangan dalam kalimat transformasi ganda gabung.

\section{B. KONSEP DASAR KLAUSA KOMPLEMEN}

Istilah komplemen digunakan oleh Samsuri dalam buku Analisis Bahasa (1994), sedangkan dalam buku Tata Kalimat Bahasa Indonesia (1985) dipakai istilah pelengkap dengan konsep yang sama, yaitu sebuah gatra yang berfungsi melengkapi gatra lain, seperti gatra benda, gatra kerja, gatra sifat, gatra bilangan, atau gatra depan. Istilah gatra dalam tilisan ini digunakan untuk menunjuk suatu tempat yang menduduki fungsi tertentu dalam konstruksi sintaktis yang berupa kalimat atau klausa, misalnya fungsi sabjek (S), fungsi predikat $(\mathrm{P})$, fungsi objek $(\mathrm{O})$, fungsi keterangan (Ket), dan fungsi pelengkap (Plk).

Pada kedua buku Samsuri tersebut (Analisis Bahasa dan Tata Kalimat Bahasa Indonesia), istilah klausa tidak dijelaskan secara rinci karena titik tolak pembicaraan transformasi adalah kalimat yang dijadikan landasan atau dasar pembentukan kalimat transformasi lebih lanjut. Hanya saja, ketika berbicara masalah transformasi sematan atau kalimat sematan, Samsuri mengungkapkan 
masalah klausa dalam kaitan dengan pembicaraan klausa relatif. Dalam hal ini, Samsuri (1985: 302) memberikan penjelasan sebagai berikut.

"Kalimat dasar yang menjadi kalimat pemadu dalam kalimat rumit, yang subjeknya berubah menjadi partikel yang karena identik dengan sebuah FN dalam kalimat matriks sehingga partikel yang mengacu ke $\mathrm{FN}$ itu disebut klausa relatif. Kita ketahui bahwa dalam bahasa Indonesia terdapat lima tipe kalimat dasar sehingga, baik kalimat matriks maupun kalimat pemadu dapat berwujud salah satu kalimat dasar itu."

Kutipan tersebut menggambarkan bahwa klausa tercermin dalam bentuk kalimat dasar, sedangkan kalimat dasar berisi sebuah satuan sintaktis yang berfungsi subjek (S) dan satuan sintaktis lain yang berfungsi predikat (P). Fungtor $\mathrm{S}$ dan $\mathrm{P}$ tersebut sebagai pengisi gatra utama pada kalimat dasar. Hal ini berarti, ada kemungkinan kedua fungtor tersebut disertai fungtor lain, seperti fungtor objek $(\mathrm{O})$, fungtor keterangan $(\mathrm{K})$, atau fungtor pelengkap (Plk). Jadi, kalimat yang minimal berisi fungtor $\mathrm{S}$ dan $\mathrm{P}$ itulah yang dikategorikan sebagai klausa.

Konsep klausa tersebut sesungguhnya masih belum tuntas karena dalam pemakaian bahasa pada umumnya, apalagi bahasa lisan, unsur bahasa pengisi fungtor $\mathrm{S}$ seringkali tidak dinyatakan. Hal ini sering terjadi dalam bentuk kalimat transformasi ganda (rapatan dan sematan) atau kalimat majemuk, baik majemuk koordinatif maupun subordinatif. Perhatikan contoh berikut.

(1) a. Pak Daut masuk kamar karena tidak menyukai acara itu.

b. Pak Daut masuk kamar karena (Pak Daut/Ia) tidak menyukai acara itu.

(2) a. Jika tidak mengumnpulkan tugas akhir, nilai tidak dikeluarkan. b. Jika (Anda/para siswa) tidak mengumpulkan tugas akhir, nilai tidak dikeluarkan.

Kata atau frara yang berada dalam kurung pada contoh (1.b) dan (2.b) tersebut merupakan unsur bahasa pengisi fungtor $\mathrm{S}$ pada klausa subordinasi masing-masing. Hal tersebut tidak dinyatakan pada contoh (1.a) dan (2.a). Kalimat (1.a) dan (2.a) masing-masing sebagai kalimat transformasi ganda yang disebut Samsuri (1985) sebagai transformasi rapatan, sedangkan secara tradisional hal itu dikategorikan sebagai kalimat majemuk bertingkat atau kalimat majemuk subordinatif. Kalimat (1.a) terdiri atas klausa utama PakDaut masuk kamar dan (Pak Daut) tidak menyukai acara itu yang digabungkan dengan konjungsi subordinasi karena yang menunjukkan makna hubungan 'sebab'. Kalimat (2.a) terdiri atas dua klausa pula, yaitu nilai tidak dikeluarkan sebagai klausa utama dan Anda tidak mengumpulkan tugas akhir yang digabungkan dengan konjungsi jika yang menyatakan makna hubungan 'kondisional/syarat'. Perlu ditambahkan di sini bahwa konjungsi karena dan jika pada kalimat (1.a) dan (2.a) tersebut masing-masing menjadi bagian langsung pada klausa subordinatif.

Dari uraian tersebut dapat dinyatakan bahwa secara normatif, klausa itu minimal terdiri atas unsur S dan P. Namun, dalam pemakaian bahasa, di antara dua unsur pokok tersebut yang harus hadir adalah unsur $\mathrm{P}$, sedangkan unsur $\mathrm{S}$ kadang-kadang ditiadakan apabila unsur $\mathrm{S}$ pada klausa bawahan sama dengan unsur S pada klausa utama. Oleh sebab itu, Ramlan (1981: 62) menegaskan bahwa klausa merupakan satuan gramatik yang terdiri atas unsur P, baik disertai unsur S, O, Plk, Ket, maupun tidak. Dengan demikian, struktur sebuah klausa adalah (S) P (O) (Plk) (Ket). Struktur ini berarti bahwa fungtor paling utama dalam sebuah klausa adalah $\mathrm{P}$, sedangkan fungtor-fungtor yang lain (yang berada dalam kurung) berpotensi tidak dinyatakan atau tidak dihadirkan. 
Kembali pada masalah klausa komplemen yaitu klausa yang menjadi pelengkap terhadap gatra (benda, kerja, sifat, bilangan, atau gatra depan). Dalam hal ini, Samsuri (1994) menggunakan istilah komplemen gatra. Namun, dalam bukunya yang lain (1985) digunakan istilah yang berbeda yaitu pelengkap frasa dengan konsep yang kurang lebih sama. Padahal, kedua istilah tersebut sesungguhnya berlainan. Gatra berkaitan dengan masalah fungtor atau fungsi sintaktis, sedangkan frasa sebagai satuan gramatik yang akan mengisi gatra-gatra dalam kalimat. Dalam teori Tata Bahasa Transformasi, frasa sebagai satuan gramatik dapat berupa kata atau kelompok kata. Jadi, frasa merupakan satuan gramatik pengisi gatra, sedangkan gatra sebagai tempat yang menduduki fungsi tertentu dalam konstruksi sintaktis yang berupa kalimat atau klausa.

Oleh karena istilah komplemen sering disamakan dengan istilah pelengkap, dalam tulisan ini istilah klausa komplemen dapat diidentikkan dengan istilah klausa pelengkap. Namun, istilah klausa pelengkap berbeda dengan iatilah gatra pelengkap. Klausa pelengkap merupakan klausa yang melengkapi gatra tertentu dalam kalimat sehingga sering disebut pelengkap gatra. Hal ini berbeda dengan istilah gatra pelengkap karena istilah gatra pelengkap merujuk pada salah satu jenis fungtor dalam kalimat, yakni Plk, sedangkan jenis fungtor yang lain adalah $\mathrm{S}, \mathrm{P}, \mathrm{O}$, dan Ket. Untuk menghindari kemungkinan kesalahpahaman antara kedua istilah tersebut, sebaiknya digunakan istilah klausa komplemen yaitu klausa yang melengkapi gatra tertentu dalam kalimat. Oleh karena gatra-gatra dalam kalimat dapat diisi oleh kategori benda, kerja, sifat, bilangan, atau frasa depan, klausa komplemen dapat memberikan kelengkapan terhadap gatra benda, kerja, sifat, bilangan, atau gatra depan tersebut. Bagaimana fungsi klausa komplemen terhadap gatra-gatra dalam kalimat? Persoalan ini akan dibicarakan lebih lanjut pada sub-bagian berikut.

\section{FUNGSI KLAUSA KOMPLEMEN DALAM TRANSFORMASI SEMATAN}

Oleh karena masalah klausa komplemen itu terdapat dalam transformasi sematan, lebih dahulu dalam bagian ini dikemukakan konsep kalimat transformasi sematan atau lebih sederhana cukup disebut transformasi sematan. Samsuri (1994) mengungkapkan bahwa kalimat transformasi sematan dibentuk dengan cara memasukkan atau menyisipkan kalimat yang satu ke dalam kalimat yang lain sebagai bagiannya. Transformasi ini dimungkinkan oleh karena sifat gatra benda yang merangkum secara alternatif kalimat baru sehingga penyematan/ penyisipan (embedding) kalimat ke dalam kalimat lain dapat dilakukan. Untuk mempermudah penyajiannya, kalimat yang disisipkan atau yang dipadukan disebut kalimat paduan dan strukturnya disebut struktur paduan (SP), sedangkan kalimat tempat memadukan disebut kalimat matriks dan strukturnya disebut struktur matriks (SM).

Setelah kalimat paduan menyatu dalam kalimat matriks, terjadilah kalimat baru yang dinamai kalimat transformasi sematan atau paduan. Dalam bentuk kalimat yang baru itu, kalimat paduan bergeser statusnya sebagai klausa paduan dan kalimat matriks sebagai klausa matriks atau klausa utama/inti. Secara sintaktis, klausa paduan sebagai subordinat dari klausaa matriks yang menjadi klausa utama pada kalimat transformasi sematan yang bersangkutan. Dilihat dari proses dan hubungan antara klausanya, kalimat transformasi sematan ini secara tradisional atau struktural, tergolong pada jenis kalimat majemuk bertingkat atau subordinatif.

Dilihat dari segi fungsi, klausa paduan dalam transformasi sematan memiliki dua kemungkinan fungsi pokok, yaitu sebagai atribut terhadap gatra benda yang menduduki $\mathrm{S}$ atau $\mathrm{O}$, dan sebagai komplemen atau pemerlengkap (istilah yang dipakai Lapoliwa, 1990) terhadap gatra benda, kerja, sifat, bilangan, atau gatra depan. Masalah klausa paduan yang berfungsi sebagai atribut terhadap gatra benda yang menduduki $\mathrm{S}$ dan $\mathrm{O}$ tidak 
dikupas lebih lanjut karena memang tidak menjadi fokus pembahasan dalam tulisan ini. Yang akan dikupas lebih lanjut adalah klausa paduan yang berfungsi sebagai komplemen atau pemerlengkap terhadap gatra.

Samsuri (1985 dan 1994) mengungkapkan bahwa klausa komplemen berfungsi untuk melengkapi gatra benda (baik yang berfungsi S maupun O), gatra kerja, gatra sifat, gatra bilangan, dan gatra depan. Perhatikan contoh berikut.

(1) a. Pendapat (bahwa koleson dapat mempertinggi daya tahan) itu menggairahkan si tua bangka.

b. Salim menyangkal berita (bahwa Pak Karto mencuri ayam).

(2) a. Perempuan itu membujuk anaknya (untuk membeli rumah di kota).

b. Ia pergi (untuk mencari nafkah).

(3) a. Mereka itu ragu (apakah harga BBM tidak naik).

b. Gaji guru hanya cukup(untuk hidup seminggu).

(4) a. Asrama itu dua buah (untuk menampung anak SD).

b. Kakek ke Jakarta (untuk mengurus paspor).

Contoh kalimat (1) sampai dengan (4) tersebut merupakan kalimat transformasi sematan. Satuan gramatik yang berada di antara kurung kecil tersebut sebagai klausa paduan, sedangkan yang berada di luar kurung kecil sebagai klausa matriks. Menurut Samsuri (1994 dan 1985), klausa paduan pada kalimat (1.a) menjadi komplemen terhadap gatra benda pendapat (itu) yang berfungsi sebagai subjek pada klausa matriks, sedangkan klausa paduan pada kalimat (1.b) menjadi komplemen terhadap gatra benda berita yang berfungsi sebagai objek pada klausa matriks. Penyematan klausa paduan tersebut ke dalam klausa matriks menggunakan partikel penyemat bahwa. Dalam hal ini muncul persoalan, apakah partikel penyemat yang dapat digunakan dalam klausa komplemen gatra benda (baik sebagai $\mathrm{S}$ maupun O) hanya kata bahwa? Di samping itu, apakah kehadiran partikel penyemat bahwa dalam kalimat tersebut bersifat wajib atau manasuka? Kedua masalah inilah yang belum dikemukakan oleh Samsuri dalam pembicaraan klausa komplemen gatra benda. Hemat saya (yang masih perlu pengkajian lebih lanjut), partikel penyemat lain yang memungkinkan dipakai dan setara dengan penyemat bahwa adalah partikel kalau. Dalam bahasa tulis (formal) partikel penyemat bahwa atau kalau dapat dinyatakan bersifat wajib, sedangkan dalam bahasa lisan (pergaulan) partikel tersebut ada kecenderungan bersifat manasuka. Perhatikan variasi contoh kalimat berikut.

(5) a. Pendapat (kalau koleson mempertinggi daya tahan) itu menggairahkan si tua bangka.

b. *Pendapat (koleson mempertingga daya tahan) itu menggairahkan si tua bangka. (Ini hanya dimungkinkan terjadi dalam bahasa lisan)

(6) a. Salim menyangkal berita (kalau Pak Karto mencuri ayam).

b. *Salim menyangkal berita (Pak Karto mencuri ayam). (bahasa lisan)

Klausa komplemen pada kalimat nomor (2) berfungsi melengkapi gatra kerja yang menduduki fungsi $P$ dalam klausa matriks. Predikat pada kalimat (2.a) diisi kata kerja transitif, sedangkan predikat pada kalimat (2.b) diisi kata kerja intransitif. Meskipun demikian, partikel penyemat yang digunakan sama yaitu untuk. Hemat saya, masih ada partikel penyemat lain yang setingkat dengan partikel untuk, yaitu kata guna. Partikel penyemat tersebut seringkali (terutama dalam bahasa lisan) tidak dinyatakan. Oleh sebab itu, Samsuri menyatakan bahwa partikel penyemat tersebut bersifat manasuka. Dengan demikian, kalimat (2.a dan b) dapat divariasikan menjadi kalimat (7.a dan b) berikut. 
(7) a. Perempuan itu membujuk anaknya (membeli rumah di kota).

b. Ia pergi (mencari nafkah).

Pada contoh kalimat nomor (3), klausa komplemen berfungsi melengkapi gatra sifat yang menduduki $\mathrm{P}$ dalam klausa matriks. Partikel penyemat yang digunakan pada kalimat (3.a) adalah apakah, sedang yang dipakai pada kalimat (3.b) adalah untuk. Perbedaan penggunaan kedua partikel tersebut dan bagaimana statusnya dalam struktur kalimat yang bersangkutan belum dijelaskan oleh Samsuri, baik pada buku pertama maupun kedua. Demikian pula, penggunaan partikel penyemat untuk pada komplemen gatra sifat dan partikel penyemat untuk pada komplemen gatra kerja belum dijelaskan bedanya. Oleh sebab itu, hal ini merupakan suatu masalah yang perlu dikaji lebih lanjut.

Terhadap permasalahan tersebut, dapat diberikan penjelasan sebagai berikut. Dilihat dari segi semantis, partikel penyemat apakah pada kalimat (3.a) menunjukkan makna 'keraguan', sedangkan partikel penyemat untuk pada kalimat (3.b) menunjukkan makna 'kegunaan'. Secara sintaktis, partikel penyemat tersebut bersifat wajib yang berbeda dengan partikel penyemat pada kalimat (2.a dan b) yang bersifat manasuka. Untuk membuktikan bahwa partikel penyemat pada komplemen gatra sifat itu bersifat wajib, dapat dilihat pada contoh (8.a dan b) berikut yang tidak menggunakan partikel penyemat sehingga secara formal kalimatnya mernjadi tidak berterima.

(8) a. *Mereka itu sangat ragu harga BBM tidak naik.

b. *Gaji guru hanya cukup hidup seminggu.

Kalimat nomor (8) tersebut sering dijumpai dalam bahasa lisan nonformal, sedangkan dalam pemakaian bahasa formal, struktur kalimat (8.a dan b) tersebut kurang berterima. Kalau hal itu dipaksakan, ada kemungkinan masih dapat dipahami apabila dalam pengekspresiannya ada jeda yang cukup di antara klausa paduan dan klausa matriks.

Pada contoh kalimat (4.a) terkandung klausa komplemen yang berfungsi melengkapi gatra bilangan dua buah yang menduduki fungsi $\mathrm{P}$ dalam klausa matriks asrama itu dua buah. Pada contoh kalimat (4.b) terkandung klausa komplemen yang melengkapi gatra depan ke Jakarta yang menduduki fungsi $\mathrm{P}$ dalam klausa matriks Kakek ke Jakarta. Partikel penyemat yang dipergunakan dalam kedua jenis kalimat tersebut sama, yaitu untuk, meskipun kategori pengisi $\mathrm{P}$ yang dilengkapi berlainan.

Menurut Samsuri (1985), gatra bilangan dan gatra depan yang menduduki fungsi $\mathrm{P}$ tersebut menunjukkan gejala yang sama. Oleh sebab itu, keduanya dijadikan satu pembicaraan dengan nama rangkuman frasa NUP (frasa numeral dan frasa preposisi). Klausa komplemen untuk kedua gatra itu hanya satu tipe, yaitu GB + GK (FN + FV), dengan partikel penyemat untuk yang menunjukkan makna 'kegunaan'. Oleh sebab itu, partikel penyemat untuk tersebut dapat divariasikan dengan kata lain, yaitu guna sehingga ada kemungkinan akan dijumpai kalimat (9. a dan b) berikut.

(9) a. Asrama itu dua buah (guna menampung anak SD).

b. Kakek ke Jakarta (guna mengurus paspor).

Dalam pemakaian bahasa sering dijumpai frasa/gatra preposisi/depan yang menggunakan preposisi untuk. Apabila terjadi penggunaan untuk sebagai preposisi dan untuk sebagai partikel penyemat yang hadir secara berurutan dalam sebuah kalimat transformasi sematan komplemen, Samsuri (1985:322) berpendapat bahwa preposisi harus dikalahkan (dihilangkan). Pandangan tersebut kurang tepat karena jika hal itu terjadi, makna keseluruhan kalimat akan menjadi rusak atau tak dapat dipahami, bahkan struktur kalimatnya pun akan menjadi janggal. Salah satu pemecahannya yang secara rasional dapat diterima adalah 
mengganti partikel penyemat untuk dengan partikel penyemat guna. Penggantian partikel penyemat itu tidak akan menggeser makna keseluruhan kalimat dan tidak akan merusak struktur sintaksisnya. Hal ini dapat dikemukakan contoh berikut.

(10) a. *Buku ini untuk Anda (untuk menambah koleksi buku perpustakaan).

b. Buku ini untuk Anda (guna_menambah koleksi buku perpustakaan).

Status partikel penyemat pada komplemen gatra bilangan dan gatra depan tersebut bersifat tidak wajib apabila subjek pada klausa matriks sama atau kembar dengan subjek pada klausa paduan. Dengan demikian, tidak akan terjadi struktur kalimat yang tak berterima, seperti tampak pada contoh kalimat berikut.

(11) *Kuda itu dua ekor untuk lembu itu menarik pedati.

\section{MAKNA HUBUNGAN ANTARA KLAUSA KOMPLEMEN DAN KLAUSA UTAMA}

Baik pada Analisis Bahasa (1994) maupun Tata Kalimat Bahasa Indonesia (1985), Samsuri belum berbicara secara eksplisit mengenai makna hubungan antara klausa komplemen (paduan) dan klausa utama (matriks) dalam kalimat transformasi sematan. Belum dibicarakannya masalah tersebut barangkali karena kesengajaan agar para pembaca dapat mengembangkannya lebih lanjut atau karena jumlah halaman buku yang harus dibatasi.

Terlepas dari kemungkinan alasan tersebut, sesungguhnya pembicaraan makna hubungan antara klausa paduan dan klausa matriks ini sangat penting karena hal itu akan menentukan status partikel penyemat yang digunakan bersifat wajib atau tidak. Di samping itu, hal tersebut akan memberikan informasi pula mengenai dapat atau tidak dapatnya klausa-klausa pada kalimat transformasi sematan dipermutasikan, seperti halnya klausaklausa pada kalimat transformasi rapatan. Oleh sebab itu, Samsuri belum sampai pada pengklasifikasian partikel penyemat ke dalam suatu kelompok tertentu. Partikel menyemat mana saja yang dapat digunakan secara lintas batas klausa komplemen dan partikel penyemat mana yang tidak dapat atau hanya secara khusus digunakan pada jenis klausa komplemen tertentu. Partikel mana saja yang berada dalam satu kelompok dan dapat digunakan secara bervariasi dan partikel penyemat mana saja yang tidak dapat divariasikan dengan partikel penyemat lain dalam kelompoknya. Misalnya, partikel penyemat bahwa yang digunakan dalam klausa komplemen gatra benda dapat divariasikan dengan partikel penyemat kalau yang keduanya menunjukkan makna yang sama, yaitu 'isi'. Hal ini dapat dilihat pada contoh kalimat (12.a dan b) berikut ini.

(12) a. Berita (bahwa orang tuanya sakit keras) telah diketahui.

b. Berita (kalau orang tuanya sakit keras) telah diketahui.

Untuk mendapatkan gambaran yang mendalam tentang makna hubungan antara klausa paduan dan klausa matriks dalam kalimat transformasi sematan perlu dilakukan kajian secara cermat lebih lanjut. Dari buku yang ada belum diperoleh jawaban yang lengkap tentang hal itu. Berbeda halnya dengan bahasa Inggris. Dalam bahasa Inggris pemakaian partikel penyemat "that, for, whether, dan if" masing-masing memiliki kaidah atau aturan yang jelas. Misalnya, partikel "that" hanya digunakan pada jenis kalimat finite dan noninterogative, partikel "whether" digunakan pada kalimat interogative dan nonfinite, partikel 'for' digunakan pada kalimat noninterogative dan nonfinite, dan partikel "if" digunakan dalam kalimat interogative dan finite (Radford, 1988:303). Kaidah ini memang hanya berlaku untuk bahasa Inggris, atau paling tidak dalam bahasa-bahasa yang serumpun dengan bahasa Inggris. Apakah partikel penyemat dalam bahasa Indonesia 
memiliki kemungkinan untuk dibuat kaidah seperti itu? Kaidah yang sama tentu saja tidak mungkin karena bahasa Indonesia bukan bahasa fleksi dan tidak memiliki ciri kasus, baik secara morfologis maupun secara sintaktis. Meskipun demikian, sesuai dengan sifat bahasa Indonesia sendiri, yaitu bahasa aglutinatif, penggunaan partikel penyemat dalam kalimat transformasi sematan bahasa Indonesia memiliki peluang dapat dipolakan atas dasar hubungan sintagmatik, paradigmatik, dan semantik.

\section{E. KOMPARASI ANTARA KLAUSA KOMPLEMEN DAN KLAUSA KETERANGAN}

Klausa komplemen sebagai klausa paduan terdapat pada kalimat transformasi ganda sematan atau penyisipan, sedangkan klausa keterangan sebagai klausa dasar yang memberikan keterangan terhadap klausa utama pada kalimat transformasi ganda gabung subordinatif. Kalimat transformasi ganda sematan dibentuk dengan cara menyematkan atau menyisipkan (embedding atau inserting) klausa paduan ke dalam klausa matriks, sedangkan kalimat transformasi ganda gabung dibentuk dengan cara menggabungkan dua klausa dasar atau lebih.

Penyematan klausa paduan ke dalam klausa matriks dalam kalimat transformasi sematan digunakan operator yang berupa partikel penyemat, sedangkan penggabungan (Samsuri menggunakan istilah rapatan) dua klausa dasar atau lebih dalam kalimat transformasi ganda gabung digunakan operator yang berupa konjungsi gabung. Klausa komplemen yang dipadukan ke dalam klausa matriks pada transformasi sematan berperan "melengkapi" salah satu gatra pada klausa matriks, sedangkan klausa keterangan pada transformasi ganda gabung berperan "menerangkan" klausa utamanya. Operator gabung pada transformasi ganda gabung bersifat wajib, sedangkan operator penyemat pada transformasi ganda sematan ada yang wajib dan ada yang bersifat manasuka.
Misalnya, operator penyemat untuk pada komplemen gatra kerja dapat hadir secara eksplisit dan dapat pula tidak hadir secara nyata dalam kalimat. Contoh nomor (13.a) berikut menunjukkan penggunaan operator penyemat manasuka pada komplemen gatra kerja, sedangkan contoh nomor (13.b) menunjukkan operator gabung yang bersifat wajib.

(13) a. Pak Tua menyuruh cucunya (untuk) membelikan sebungkus rokok.

b. Toni belajar tekun supaya ujiannya berhasil.

Samsuri dalam Analisais Bahasa (1994) masih menyebutkan adanya transformasi ganda gabung yang menggunakan operator gabung untuk yang diberi nama transformasi ganda gabung voletif (kehendak), sedangkan pada Tata Kalimat Bahasa Indonesia (1985) hal tersebut sudah tidak disinggung lagi. Beliau membicarakan operator untuk dalam kaitannya dengan pembicaraan transformasi ganda sematan komplemen gatra kerja dan komplemen gatra depan. Hal ini memang dapat menimbulkan kerancuan karena dalam pemakaian bahasa memang sering dijumpai kalimat transformasi ganda gabung yang menggunakan operator gabung (konjungsi) untuk atau yang sejenis, yaitu guna. Namun, di sisi lain banyak dijumpai pula kalimat transformasi sematan yang menggunakan partikel penyemat untuk dan guna. Perhatikan contoh kalimat berikut.

(14) a. Saya akan membawa masalah itu ke pengadilan (untuk membuktikan mana yang salah dan mana yang benar).

b. (Untuk membuktikan mana yang salah dan mana yang benar), saya akan membawa masalah itu ke pengadilan.

c. *Saya akan membawa masalah itu ke pengadilan (membuktikan mana yang salah dan mana yang benar).

(15) a. Suni pergi pagi-pagi (untuk mencari nafkah). 
b. Suni pergi pagi-pagi (mencari nafkah).

c. *Untuk mencari nafkah, Suni pergi pagi-pagi. (makna berubah)

Kalimat (14.a) menunjukkan bahwa operator untuk berfungsi sebagai konjungsi gabung. Pengujiannya, klausa yang didahului operator untuk dapat dipermutasikan ke awal kalimat, seperti pada kalimat (14.b), dan kalimat yang dihasilkannya tetap berterima, baik secara sintaktis maupun secara semantis. Di samping itu, konjuingsi gabung untuk tersebut bersifat wajib. Jika konjungsi gabung untuk ditanggalkan, misalnya pada kalimat (14.c), kalimat tersebut menjadi rusak, baik secara sintaktis maupun secara semantis.

Kalimat (15.a) menunjukkan bahwa operator untuk berfungsi sebagai partikel penyemat pada klausa komplemen gatra kerja. Partikel penyemat untuk tersebut bersifat manasuka sehingga kalaupun partikel tersebut ditanggalkan, misalnya tampak pada kaliomat (15.b), kalimat yang dihasilkannya tetep berterima, baik secara semantis maupun secara sintaktis. Namun, jika komplemen gatra kerja yang didahului partikel penyemat untuk tersebut dipermutasikan secara paksa, misalnya tampak pada kalimat (15.c), secara semantis kalimat yang dihasilkannya berubah atau berbeda dari makna yang terdapat pada kalimat (15.a) dan kalimat (15.b)

\section{F. PENUTUP}

Dalam buku Analisis Bahasa (1994) dan Tata Kalimat Bahasa Indonesia (1985) tidak dibicarakan secara khusus mengenai konsep klausa. Hal ini hanya disinggung pada saat berbicara masalah kalimat dasar. Istilah komplemen digunakan oleh Samsuri pada buku pertama, sedangkan dalam buku kedua digunakan istilah pelengkap dengan makna yang sama. Oleh sebab itu, istilah klausa komplemen dapat diidentikkan dengan istilah klausa pelengkap, tetapi hal tersebut berbeda dengan istilah gatra pelengkap. Klausa komplemen merupakan klausa yang melengkapi gatra yang menduduki fungsi sintaktis, sedangkan gatra pelengkap hanya merupakan salah satu jenis fungsi sintaktis.

Fungsi klausa komplemen dalam kalimat transformasi sematan melengkapi gatra benda, (baik yang berfungsai sebagai $\mathrm{S}$ maupun O), gatra kerja, gatra sifat, gatra bilangan, atau gatra preposisi, yang masing-masing menduduki fungsi $\mathrm{P}$ pada klausa matriks. Klausa komplemen sebagai klausa paduan yang disisipkan atau disematkan ke dalam klausa utama sebagai klausa matriks memberikan kelengkapan terhadap gatra tertentu pada klausa matriksnya. Penyematan klausa komplemen ke dalam klausa matriks menggunakan bantuan berupa partikel penyemat tertentu, yakni dalam komplemen gatra benda digunakan partikel penyemat bahwa, kalau; dalam komplemen gatra kerja digunakan partikel penyemat untuk, guna; dalam komplemen gatra sifat dipakai partikel penyemat apakah; dalam komplemen gatra bilangan dan gatra preposisi dapat digunakan partikel penyemat untuk atau guna.

Makna hubungan antara klausa komplemen dan klausa utama dalam kalimat transformasi sematan dapat diidentifikasi atas dasar makna sintaktis operator penyemat yang digunakan. Oleh sebab itu, akan dijumpai penggunaan operator penyemat berbeda, tetapi makana sintaktisnya sama, atau dapat pula dijumpai yang sebaliknya.

Klausa komplemen sebagai klausa paduan melengkapi gatra tertentu pada kalimat matriks/utama, sedangkan klausa keterangan sebagai klausa dasar yang memberikan keterangan terhadap kalimat matriks/utama. Klausa komplemen merupakan klausa paduan dalam kalimat transformasi sematan/ penyisipan, sedangkan klausa keterangan merupakan klausa dasar yang digabungkan dengan klausa utama pada kalimat transformasi ganda gabung subordinatif. Penyematan klausa paduan ke dalam klausa matriks dalam kalimat transformasi sematan menggunakan bantuan operator penyemat, sedangkan penggabungan klausa keterangan dengan klausa utama dalam kalimat transformasi ganda gabung menggunakan bantuan operator gabung. 


\section{DAFTAR PUSTAKA}

Coe, Norman. 1981. A Learner's Grammar of English. Ottawa: Nelson Ltd.

Djajasudarma, T. Fatimah. 1999. Penalaran Deduktif-Induktif dalam Wacana Bahasa Indonewsia. Bandung: Alqaprint.

Downing, Angela dan Philip Locke. 1990. A University Couese in English Grammar. Great Britain: Prentice Hall International, Ltd.

Lapoliwa, Hans. 1990. Klausa Pemerlengkapan dalam Bahasa Indonesia. Yogyakarta: Kanisius.

Radford, Andrew. 1988. Transformational Grammar. Cambridge: Cambridge University Press.
Ramlan, M. 1981. Ilmu Bahasa Indonesia: Sintaksis. Yogyakarta: UP Karyono.

Samsuri. 1994. Analiaia Bahasa. Jakarta: Erlangga.

Samsuri. 1985. Tata Kalimat Bahasa Indonesia. Jakarta: PT Sastra Hudaya.

Sugono, Dendy dan Titik Indiyastini. 1994. Verba dan Komplementasinya. Jakarta: Pusat Pembinan dan Pengembangan Bahasa.

Suhardi. 2005. Sintaksis. Yogyakarta: UNY Press. 